\title{
Screening for insecticidal efficacy of two Algerian essential oils with special concern to their impact on biological parameters of Ephestia kuehniella (Zeller) (Lepidoptera: Pyralidae)
}

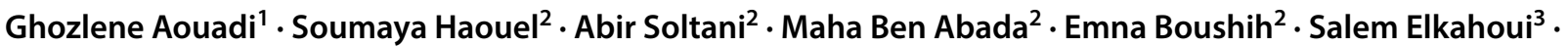 \\ Faiza Taibi ${ }^{1,4}$. Jouda Mediouni Ben Jemâa ${ }^{2}$. Salima Bennadja ${ }^{4}$
}

Received: 25 December 2019 / Accepted: 28 May 2020 / Published online: 7 June 2020

(c) The Author(s) 2020

\begin{abstract}
Chemical composition of Algerian Mentha rotundifolia and Myrtus communis essential oils, their insecticidal activities and their impact on some biological parameters of the Mediterranean flour moth Ephestia kuehniella were assessed. Results showed that $M$. rotundifolia essential oil contained piperitenone oxide (46.06\%), D-limonene (9.10\%), cis-piperitone oxide $(6.81 \%)$, and endo-borneol (4.64\%) as major compounds, while M. communis oil was rich in $\alpha$-pinene (29.08\%), 1,8 -cineole $(36.82 \%)$, $\alpha$-terpineol $(6.42 \%)$, geranyl acetate $(4.38 \%)$, and $\beta$-linalool $(4.04 \%)$. The fumigant potential and contact toxicity tests against E. kuehniella demonstrated the effectiveness of $M$. rotundifolia essential oil $\left(\mathrm{LC}_{50}=0.54 \mu \mathrm{L} / \mathrm{L}\right.$ air, $\left.\mathrm{LC}_{50}=0.004 \mu \mathrm{L} / \mathrm{cm}^{2}\right)$ compared to $M$. communis oil $\left(\mathrm{LC}_{50}=2.91 \mu \mathrm{L} / \mathrm{L}\right.$ air, $\left.\mathrm{LC}_{50}=0.025 \mu \mathrm{L} / \mathrm{cm}^{2}\right)$. Moreover, results revealed that all biological parameters were significantly affected (fecundity: 6 eggs/female, oviposition deterrence: $96.62 \%, \log$ fertility: 0 , hatching rate: $0 \%$, copulation rate: $0 \%$ for $M$. rotundifolia oil against fecundity: 93 eggs/female, percentage of oviposition deterrence: $47.85 \%$, log fertility: 6.7 , hatching rate: $57 \%$, copulation rate: $53.33 \%$ for $M$. communis oil). This work supports the use of botanical insecticide as active pest control agents under storage conditions.
\end{abstract}

Keywords Ephestia kuehniella $\cdot$ Essential oil $\cdot$ Round-leaved mint $\cdot$ Common myrtle $\cdot$ Copulation rate

\section{Introduction}

Agricultural products are often subject to biotic and abiotic damage during production and conservation. Contamination of food commodities by insect pests is an important quality control issue of concern for the food industries (Rajendran and Sriranjini 2008). About 35\% on the field

Ghozlene Aouadi

ghozleneaouadi@yahoo.fr

1 Laboratoire de Biodiversité et Pollution des Écosystèmes, Université Chadli Bendjedid, Bp 76, El-Taref, Algerie

2 Laboratoire de Biotechnologie Appliquée à l'Agriculture, INRAT, Université de Carthage, Rue Hedi Karray, 1004 El Menzah, Tunis, Tunisia

3 Department of Biology, College of Science, University of Ha'il, PO Box 2440, Hail 81451, Kingdom of Saudi Arabia

4 Laboratoire de Biochimie et Toxicologie Environnemental, Département de Biochimie, Faculté des Sciences, Université Badji Mokhtar, Bp 12, Annaba, Algerie and 14\% in storage (around 50\% in total) crops are lost annually because of insect pests, which adversely affected the world food production during crop growth, harvest and storage (Jitendra et al. 2009). Among damaging insects, the Mediterranean flour moth Ephestia kuehniella Zeller (Lepidoptera: Pyralidae) is one of the major pests in industrial flour mills (Jacob and Cox 1977), in Algeria (Hami et al. 2005) and Tunisia (Jarraya 2003). It is a worldwide pest that causes major economic losses in the Mediterranean basin and near East regions (Al-Izzi et al. 1985). Its main habitats are flour and grout mills, corn milling plants, bakeries and any other place used for processing grains or preparing flour products (Ben Achour et al. 2008). Larvae of E. kuehniella reduce both quantitative and qualitative quality of the products by feeding, by their presence and by the production of feces and webbing (Johnson et al. 1997). Last years, the overuse of synthetic insecticides and fumigants such as phosphine for grain storage has resulted in a number of problems, including the development of insecticide resistance among insect pests of stored grains (Sousa et al. 2009). Currently, stored-product pest control 
strategies tend to emphasize the non-chemical aspects of pest control with the judicious use of pesticides (Titouhi et al. 2017). In this respect, plant extracts are safe, ecofriendly and more compatible with environmental components compared to synthetic pesticides and so ranked under Green pesticides category (Rahman et al. 2016).

Besides, Kim et al. (2003) showed that plant extracts are often active against a limited number of target insects, are biodegradable, and are potentially suitable for use in integrated pest management. These authors reported also that plant extracts could lead to the improvement in new classes of nontoxic insect control. Plant essential oils have been recently qualified as ecological alternatives to chemical pesticides due to their multifunctional efficacy including anti-insect pest activity (Isman and Grieneisen 2014; Mediouni Ben Jemâa 2014). Furthermore, essential oils possess important contact and fumigant toxicity (Liu and Ho 1999; Abdelgaleil et al. 2009; Kasrati et al. 2015; Quan et al. 2018), antifeedant activity (Huang et al. 1997; Ebadollahi 2013), repellent activity (Hori 2003; Prajapati et al. 2005; Nerio et al. 2009; Chang et al. 2017) as well as development and growth inhibitory activity (Waliwitiya et al. 2009; Sangha et al. 2017) against various insect species and are regarded as environmentally compatible pesticides (Cetin et al. 2004).

Their lipophilic nature facilitates their interference with basic metabolic, biochemical, physiological and behavioral functions of insects (Nishimura 2001). Commonly, essential oils with anti-insect pest ability are known to possess insecticidal and repellent effects by neurotoxic mode of action (Kostyukovsky et al. 2002). Mentha rotundifolia (L.) huds (Lamiales: Lamiaceae) and Myrtus communis (L.) (Myrtales: Myrtaceae) are commonly known under the vernacular names of round leaf and common myrtle. These aromatic plant species, grow wild in northern Algeria, are widely used by the population in traditional phytotherapy for their therapeutic virtues. The essential oils extracted from the leaves of Myrtus communis have shown insecticidal activity against E. kuehniella, Plodia interpunctella, Acanthoscelides obtectus (Ayvaz et al. 2010), Tribulium castaneum (Senfi et al. 2013), Callosobruchus maculatus (Khani and Farzaneh 2012), and Trogoderma granarium (Tayoub et al. 2012). Few studies have reported the insecticidal potential of $M$. rotundifolia essential oil on stored-product pests (El Arch et al. 2003; Brahmi et al. 2016). Nevertheless, no study has been reported before on the insecticidal activity of $M$. rotundifolia against E. kuehniella adults.

This work aimed to assess the fumigant and contact toxicity of $M$. rotundifolia and $M$. communis essential oils from Algeria as well as their effects on longevity, fecundity, fertility, copulation rate and hatching rate against new emerged adults of a Tunisian strain of the Mediterranean flour moth E. kuehniella.

\section{Materials and methods}

\section{Insect rearing}

A rearing colony of $E$. kuehniella was maintained on wheat flour and semolina under laboratory-controlled condition (temperature of $25{ }^{\circ} \mathrm{C} \pm 1{ }^{\circ} \mathrm{C}$, a relative humidity of $65 \pm 5 \%$ and darkness). Insects were maintained in 2-L plastic storage boxes. Unsexed adults aged between 24 and $48 \mathrm{~h}$ were used for the bioassays.

\section{Plant material}

Myrtus communis aerial parts samples were collected during October 2017 from the Edough Massif (North-East AlgeriaAnnaba: $36^{\circ} 55^{\prime} \mathrm{N}, 7^{\circ} 36^{\prime} \mathrm{E}$ ), while M. rotundifolia aerial parts were sampled during August 2018 from the locality of Berrahal (North-East of Algeria-Annaba: $36^{\circ} 50^{\prime} \mathrm{N}, 7^{\circ}$ $\left.27^{\prime} \mathrm{E}\right)$.

\section{Extraction of the essential oils}

$100 \mathrm{~g}$ of dry leaves of each plant was hydrodistilled during 90 min using a Clevenger apparatus. The crude-extracted essential oils were stored in opaque flasks in a refrigerator at $4{ }^{\circ} \mathrm{C}$. Essential oils' yields obtained from each plant species were evaluated according to AFNOR (1986) formula: oil\% $(\mathrm{w} / \mathrm{w})=$ weight of essential oil $(\mathrm{g}) /$ weight of plant material $(\mathrm{g}) \times 100$.

\section{Gas chromatography-mass spectrometry (GC/MS) analysis}

The analysis was carried out using an Agilent 7890A gas chromatograph combined to an Agilent 5972C mass spectrometer with electron impact ionization $(70 \mathrm{eV})$. The mass spectrometer was equipped with a capillary column HP-5 MS (19091S-433), length $30 \mathrm{~m}$, diameter $250 \mu \mathrm{m}$, and $2.5 \mu \mathrm{m}$ film thicknesses (5\% phenyl methyl silicone, 95\% dimethylpolysiloxane; Hewlett-Packard, CA, USA). The column temperature was automated to rise from 50 to $250{ }^{\circ} \mathrm{C}$ at a rate of $7{ }^{\circ} \mathrm{C} / \mathrm{min}$. The transfer line temperature was $250^{\circ} \mathrm{C}$. The flow rate of helium (carrier gas) was $1 \mathrm{~mL} / \mathrm{min}$. A sample of $2 \mu \mathrm{L}$ was manually injected with a constant pressure of 7.65 psi using split mode (split ratio 50:1). Scan time and mass range were $1 \mathrm{~s}$ and of $45-400 \mathrm{~m} / \mathrm{z}$, respectively. The essential oils components were identified by comparing their retention indices (RIs) relative to $n$-alkanes with those of authentic compounds published in the literature or available in our laboratory. Furthermore, the identification was confirmed by matching 
their mass spectra with those recorded in Wiley Registry 9th Edition/NIST 2011 edition mass spectral library. The composition of the essential oils was stated as a relative percentage of total peak area.

\section{Bioassays}

\section{Fumigant toxicity}

The insecticidal activity of $M$. rotundifolia and $M$. communis essential oils was evaluated by the fumigant test according to Titouhi et al. (2017). Ten adults of E. kuehniella were placed in Plexiglas bottles of $38 \mathrm{~mL}$ volume. The bottom surface of the screw caps was lined with Whatman $\mathrm{n}^{\circ} 1$ paper disks $(2 \mathrm{~cm}$ diameter with a $3 \mathrm{~cm}$ length fixing tab). Using a micropipette, a series of essential oils doses (without the use of any solvent) were deposited on the filter paper disks. Doses used in the essay were $0.05,0.125$, and $0.5 \mu \mathrm{L}$ giving equivalent concentrations of $1.31,3.28$, and $13.16 \mu \mathrm{L} / \mathrm{L}$ air. The caps were quickly screwed tightly onto the bottles. Three repetitions were carried out for each concentration of each essential oil including a negative control without essential oil and maintained under the same conditions described for breeding. Mortality was assessed by direct observation of insects every hour until total death. Insects are considered dead when no leg or antenna movements have been observed. Mortality was adjusted via the Abbott correction formula (Abbott 1925). Probit analysis (IBM SPSS V22.0) was used to estimate lethal concentrations $\mathrm{LC}_{50}$ and $\mathrm{LC}_{95}$ values and lethal time $\mathrm{LT}_{50}$.

\section{Contact toxicity}

The contact bioassay of $M$. communis and M. rotundifolia essential oils against $E$. kuehniella adults was done according to Mami Maazoun et al. (2017). A Whatman filter paper disks, having $9 \mathrm{~cm}$ of diameter, were treated with three doses $0.05,0.125$, and $0.5 \mu \mathrm{L}$ dissolved in acetone to give concentrations equivalent to $9 \times 10^{-4}, 24 \times 10^{-4}$, and $99 \times 10^{-4} \mu \mathrm{L} /$ $\mathrm{cm}^{2}$. Acetone was used as a negative control. The solvent was allowed to evaporate completely at room temperature for $5 \mathrm{~min}$. Each filter paper disk was then placed in a glass Petri dish, and 10 adults of E. kuehniella were placed into the center of each Petri dish. Each hour, the number of dead insects was recorded. Tests were done in triplicate. The percentage of mortality was calculated using Abbott's correction formula (1925). Insects are considered dead when no leg or antenna movements have been observed. The $\mathrm{LC}_{50}$, $\mathrm{LC}_{95}$, and $\mathrm{LT}_{50}$ values were calculated by using Probit analysis (IBM SPSS V20.0).

\section{Impact on biological parameters}

The insecticidal effects of $M$. communis and $M$. rotundifolia essential oils through fumigation were studied by assessing their impact on longevity, fecundity, fertility, hatching rate, percentage of oviposition deterrence, and copulation rate of E. kuehniella. Five pairs of unsexed adults (0-24 h old) were exposed at the lethal concentration $\mathrm{LC}_{15}$. The longevity of males and females, the total number of eggs laid per female (fecundity), the percentage of oviposition deterrence according to Pascual Villalobos and Robledo (1998), fertility, and the percentage of egg hatching were determined. Non-exposed adults kept under the same conditions served as a control. Experiments were replicated three times. For the copulation rate study, prior to exposure, virgin females were obtained by rearing last instar larvae of E. kuehniella separately in plastic boxes. Female's bursa copulatrix were dissected out under a binocular microscope in a saline solution $(10 \% \mathrm{NaCl})$ and observed for the presence of spermatophores as a criterion of successful mating.

\section{Data analysis}

For each biological parameter (longevity, percentage of oviposition deterrence, fecundity, fertility, hatching rate, and copulation rate of E. kuehniella), data were subjected to two-way ANOVA, with essential oils and exposure time as main fixed factors plus with essential oils* exposure time interaction term. Differences in values of each essential oil and exposure time were tested by one-way ANOVA followed by Duncan test to detect significant differences in means at 0.05 percent level. In some cases, certain data have been transformed into a common logarithm or square root in order to obtain a normal distribution of the variables. All data values represented the mean of three replications and were expressed as the mean \pm standard deviation. All statistical analyses were achieved using SPSS statistical software version 22.0.

\section{Results}

\section{Essential oil composition}

Oil yields based on leaf dry matter weight were, respectively, $1.29 \%$ and $0.64 \%$ for $M$. rotundifolia and M. communis. GC and GC/MS analysis of $M$. rotundifolia and M. communis essential oils are reported in Table 1. Results indicated that M. rotundifolia essential oil contained 30 identified compounds constituting approximately $95.51 \%$ of the total content. The essential oil profile was characterized by piperitenone oxide (46.06\%), D-limonene $(9.10 \%)$, cis-piperitone 
Table 1 Essential oil composition (\%) of Mentha rotundifolia and Myrtus communis leaves collected from Algeria

\begin{tabular}{|c|c|c|c|c|}
\hline No. & Compounds & RI & M. rotundifolia & M. communis \\
\hline 1 & $\alpha$-Pinene & 939 & 2.61 & 29.08 \\
\hline 2 & Camphene & 954 & 1.69 & 1.91 \\
\hline 3 & Sabinene & 976 & 0.91 & - \\
\hline 4 & Vinyl amyl carbinol & 978 & 1.44 & - \\
\hline 5 & $\beta$-Pinene & 980 & 2.04 & 0.77 \\
\hline 6 & $\beta$-Myrcene & 991 & 1.39 & - \\
\hline 7 & $\beta$-Ocimene & 995 & 0.27 & - \\
\hline 8 & $\Delta$-3-Carene & 1011 & - & 0.64 \\
\hline 9 & $p$-Cimene & 1023 & - & 1.52 \\
\hline 10 & D-Limonene & 1028 & 9.10 & - \\
\hline 11 & 1,8-Cineole & 1033 & 0.45 & 36.82 \\
\hline 12 & $\gamma$-Terpinene & 1053 & - & 0.53 \\
\hline 13 & $\alpha$-Terpinolene & 1089 & - & 0.47 \\
\hline 14 & $\beta$-Linalool & 1098 & - & 4.04 \\
\hline 15 & $\begin{array}{l}\text { Amyl vinyl carbinyl } \\
\text { acetate }\end{array}$ & 1110 & 0.67 & - \\
\hline 16 & trans-Pinocarveol & 1138 & - & 1.04 \\
\hline 17 & Camphor & 1143 & 0.57 & 0.46 \\
\hline 18 & $(R)$-Lavandulol & 1148 & 0.26 & - \\
\hline 19 & Endo-borneol & 1165 & 4.64 & - \\
\hline 20 & Terpinen-4-ol & 1178 & 0.35 & 1.09 \\
\hline 21 & $\alpha$-Terpineol & 1189 & 0.82 & 6.42 \\
\hline 22 & $\begin{array}{l}\text { 5-acetyl-2-hydrazino-4 } \\
\text { methylpyrimidine }\end{array}$ & 1211 & 1.85 & - \\
\hline 23 & trans-Carveol & 1230 & - & 0.33 \\
\hline 24 & Geraniol & 1255 & - & 1.15 \\
\hline 25 & Linalyl acetate & 1257 & - & 0.51 \\
\hline 26 & cis-Piperitone oxide & 1261 & 6.81 & - \\
\hline 27 & Bornyl acetate & 1285 & 0.52 & - \\
\hline 28 & m-Thymol & 1290 & 0.37 & - \\
\hline 29 & Piperitenone oxide & 1376 & 46.06 & - \\
\hline 30 & Geranyl acetate & 1383 & - & 4.38 \\
\hline 31 & cis-Jasmone & 1394 & 2.47 & - \\
\hline 32 & Methyl eugenol & 1401 & - & 2.59 \\
\hline 33 & Caryophyllene & 1420 & 3.18 & 0.42 \\
\hline 34 & $\alpha$-Humulene & 1454 & 0.42 & - \\
\hline 35 & trans- $\beta$-farnesene & 1458 & 0.87 & - \\
\hline 36 & $\alpha$-Amorphene & 1475 & 0.34 & - \\
\hline 37 & Germacrene D & 1485 & 3.58 & - \\
\hline 38 & $\gamma$-Cadinene & 1513 & 0.46 & - \\
\hline 39 & 1S.cis-calamenene & 1519 & 0.50 & - \\
\hline 40 & Caryophyllene oxide & 1581 & - & 0.96 \\
\hline 41 & Veridiflorol & 1592 & 0.47 & - \\
\hline 42 & $\alpha$-Cadinol & 1643 & 0.40 & - \\
\hline Total & & & 95.51 & 95.13 \\
\hline
\end{tabular}

-, compound not detected; RI, retention index calculated on a HP$5 \mathrm{MS}$ capillary column $(30 \mathrm{~m} \times 0.25 \mathrm{~mm} \times 0.25 \mathrm{~mm})$ oxide (6.81\%), and endo-borneol (4.64\%). Concerning the essential oil of $M$. communis, 20 compounds representing $95.13 \%$ of the total oil composition were identified. The major components were $\alpha$-pinene $(29.08 \%), 1,8$-cineole (36.82\%), $\alpha$-terpineol (6.42\%), geranyl acetate $(4.38 \%)$, and $\beta$-linalool (4.04\%).

\section{Essential oil fumigant toxicity}

Fumigant toxicity results are presented in Fig. 1 as a percentage of mortality of E. Kuehniella adult's strains from Tunisia exposed to $M$. rotundifolia and $M$. communis essential oils collected from Algeria. Data revealed that fumigant toxicity depended significantly on plant species $\left(F_{1,36}=33.02\right.$, $p<0.01)$, concentrations $\left(F_{2,36}=20.01, p<0.01\right)$, and exposure time $\left(F_{1,36}=4.82, p<0.01\right)$. The mortality values increased depending on the increasing essential oil concentrations. Furthermore, M. rotundifolia essential oil was more toxic than $M$. communis. In fact, for the lowest concentration $(1.31 \mu \mathrm{L} / \mathrm{L}$ air), percentage mortality of E. kuehniella after $48 \mathrm{~h}$ attained, respectively, $100 \%$ and $41.66 \%$ with $M$. rotundifolia and $M$. communis essential oils. For the highest concentration (13.16 $\mu \mathrm{L} / \mathrm{L}$ air), M. rotundifolia and $M$. communis essential oils caused $100 \%$ mortality after, respectively, 18 and $24 \mathrm{~h}$ of exposure. Moreover, essential oil of $M$. rotundifolia caused significantly the highest adulticidal effects at all tested concentrations. Moreover, results indicated that $M$. rotundifolia essential oil showed $100 \%$ effectiveness at $3.28 \mu \mathrm{L} / \mathrm{L}$ air after only $18 \mathrm{~h}$ of treatment.

Probit analyses have also confirmed that E. kuehniella was more susceptible to M. rotundifolia oil (Table 2). Additionally, the $\mathrm{LC}_{50}$ and $\mathrm{LC}_{95}$ values proved that $M$. rotundifolia essential oil was more toxic than $M$. communis. The $\mathrm{LC}_{50}$ values reached $0.54 \mu \mathrm{L} / \mathrm{L}$ air for $M$. rotundifolia and $2.91 \mu \mathrm{L} / \mathrm{L}$ air for $M$. communis. The $\mathrm{LC}_{95}$ was evaluated to be, respectively, $2.11 \mu \mathrm{L} / \mathrm{L}$ air and $5.29 \mu \mathrm{L} / \mathrm{L}$ air for $M$. rotundifolia and M. communis essential oils. Furthermore, the $\mathrm{LT}_{50}$ values ranged between 1.03 and $20.76 \mathrm{~h}$ for $M$. rotundifolia and from $20.19 \mathrm{~h}$ to $105.09 \mathrm{~h}$ for $M$. communis (Table 3).

\section{Essential oil contact toxicity}

Fumigant toxicity data are illustrated in Fig. 2 as percentage of mortality of E. kuehniella adults. Statistical analysis revealed significant differences in percentage of mortality as a function of essential oils treatments $\left(F_{1,12}=10.08\right.$, $p<0.01)$ and concentrations $\left(F_{2,12}=7.58, p<0.01\right)$ after $72 \mathrm{~h}$ of exposure. But no significant differences were detected in percentage of mortality after $120 \mathrm{~h}$ of exposure time [essential oils treatments $\left(F_{1,12}=4.00, p>0.05\right)$ and concentrations $\left.\left(F_{2,12}=1.75, p>0.05\right)\right]$. Results indicated the sensitivity of E. kuehniella adults to both essential oils 


\section{$1.31 \mu \mathrm{l} / \mathrm{l}$ air}

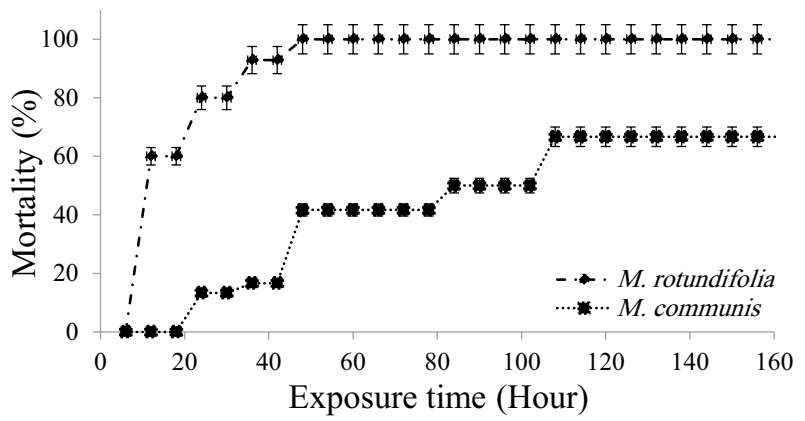

$3.28 \mu \mathrm{l} / \mathrm{l}$ air

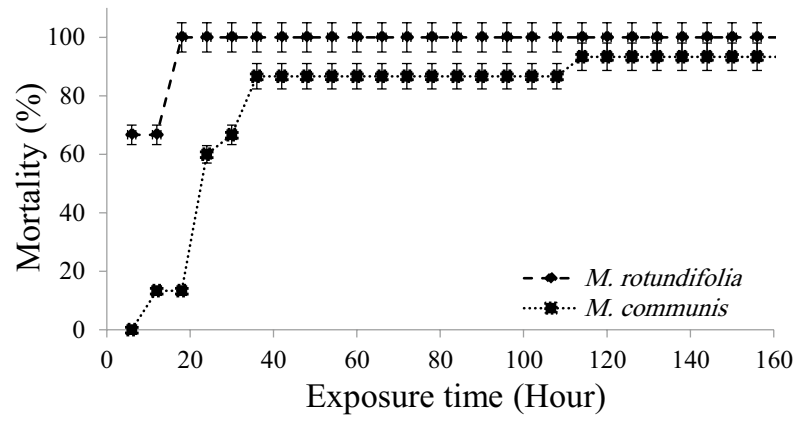

\section{$13,16 \mu \mathrm{l} / \mathrm{l}$ air}

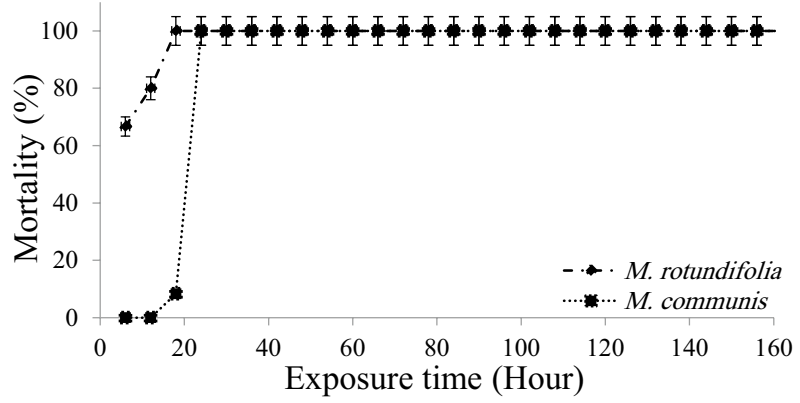

Fig. 1 Mortality (\%) of Ephestia kuehniella adults exposed for various periods of time and various concentrations to Mentha rotundifolia and Myrtus communis essential oils

Table 2 Fumigant toxicity of Mentha rotundifolia and Myrtus communis essential oils against Ephestia kuehniella

\begin{tabular}{lllllll}
\hline Essential oils & $\begin{array}{l}\mathrm{LC}(\mathrm{a}, \mathrm{b}) \\
(\mu \mathrm{L} / \mathrm{L} \text { air })\end{array}$ & $\begin{array}{l}\mathrm{LC}_{95}^{(\mathrm{a}, \mathrm{b})} \\
(\mu \mathrm{L} / \mathrm{L} \text { air })\end{array}$ & $\chi^{2}$ & Slope $\pm \mathrm{SE}$ & Sig & $\begin{array}{l}\text { Degrees } \\
\text { of free- } \\
\text { dom }\end{array}$ \\
\hline M. rotundifolia & $0.54(0.05-0.94)$ & $2.11(1.74-3.95)$ & 0.26 & $1.05 \pm 0.38$ & 0.56 & 1 \\
M. communis & $2.91(2.63-4.84)$ & $5.29(4.61-6.46)$ & 0.01 & $0.67 \pm 0.10$ & 1.00 & 1 \\
\hline
\end{tabular}

${ }^{\mathrm{a}}$ Units $\mathrm{LC}_{50}$ and $\mathrm{LC}_{95}=\mathrm{ml} / \mathrm{l}$ air. Applied for $24 \mathrm{~h}$ at $25^{\circ} \mathrm{C}$

${ }^{\mathrm{b}} 95 \%$ lower and upper confidence limits are shown in parentheses

\begin{tabular}{lccrrrr}
\hline Essential oils & $\begin{array}{l}\text { Concentration } \\
(\mu \mathrm{L} / \mathrm{L} \text { air })\end{array}$ & $\mathrm{LT}_{50}^{(\mathrm{a}, \mathrm{b})}$ & $\chi^{2}$ & Slope $\pm \mathrm{SE}$ & Sig & $\begin{array}{l}\text { Degrees of } \\
\text { freedom }\end{array}$ \\
\hline M. rotundifolia & 1.31 & $20.76(9.80-29.16)$ & 5.87 & $0.10 \pm 0.01$ & 0.31 & 5 \\
& 3.28 & $5.30(1.6-17.6)$ & 3.52 & $0.37 \pm 0.05$ & 0.10 & 5 \\
& 13.16 & $1.03(0.14-3.94)$ & 4.04 & $0.53 \pm 0.08$ & 0.20 & 5 \\
M. communis & 1.31 & $105.09(76.42-173.91)$ & 5.66 & $0.013 \pm 0.001$ & 0.34 & 5 \\
& 3.28 & $22.41(10.32-36.42)$ & 25.12 & $0.02 \pm 0.002$ & 0.00 & 5 \\
& 13.16 & $20.19(17.35-22.77)$ & 3.90 & $0.06 \pm 0.005$ & 1.00 & 5 \\
\hline
\end{tabular}

${ }^{\mathrm{a}}$ Units $\mathrm{LT}_{50}=\mathrm{h}$. Applied at $25^{\circ} \mathrm{C}$

${ }^{\mathrm{b}} 95 \%$ lower and upper confidence limits are shown in parentheses 
concentrations with a high striking effect of $M$. rotundifolia essential oil. Indeed, the lowest concentration $\left(9 \times 10^{-4} \mu \mathrm{L} /\right.$ $\mathrm{cm}^{2}$ ) of $M$. rotundifolia oil induced $100 \%$ mortality after $72 \mathrm{~h}$ of exposure, while $80 \%$ mortality was achieved after $120 \mathrm{~h}$ of exposure to $M$. communis oil.

Table 4 reports $\mathrm{LC}_{50}$ and $\mathrm{LC}_{95}$ values calculated for $M$. rotundifolia and M. communis essential oils against $E$. kuehniella adults. The median lethal concentration was

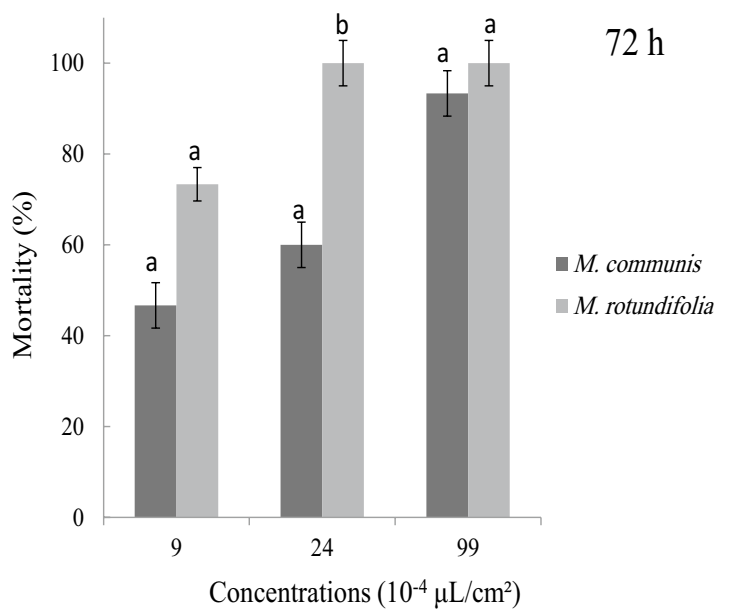

Fig. 2 Mortality (\%) of Ephestia kuehniella adults exposed for various concentrations of Mentha rotundifolia and Myrtus communis essential oils after 72 and 120 h. (For each concentration, compari- highly dependent upon oils. Probit analysis established that E. kuehniella adults were more susceptible to $M$. rotundifolia oil.

Table 5 demonstrates that $\mathrm{LT}_{50}$ values for $M$. rotundifolia ranged from $62 \mathrm{~h}$ for the lowest concentration $\left(9 \times 10^{-4} \mu \mathrm{L} / \mathrm{cm}^{2}\right)$ to $26 \mathrm{~h}$ for the highest concentration $\left(99 \times 10^{-4} \mu \mathrm{L} / \mathrm{cm}^{2}\right)$, while for M. communis oil $\mathrm{LT}_{50}$ values

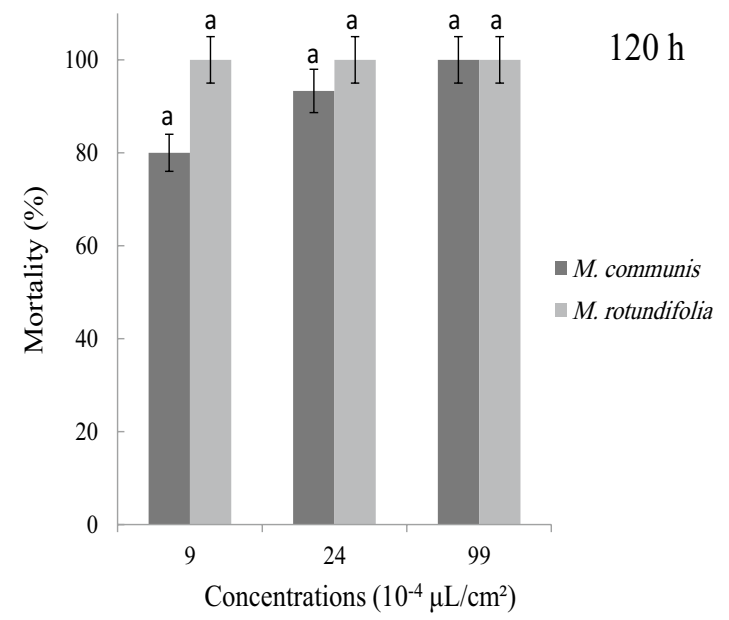

sons were made among essential oils. Different letters are significantly different according to Duncan test at $p \leq 0.05$ )
Table 4 Contact toxicity of Mentha rotundifolia and Myrtus communis essential oils against Ephestia kuehniella

\begin{tabular}{lllllll}
\hline Essential oils & $\mathrm{LC}_{50}^{(\mathrm{a} . \mathrm{b})}\left(\mu \mathrm{L} / \mathrm{cm}^{2}\right)$ & $\mathrm{LC}_{95}^{(\mathrm{a} . \mathrm{b})}\left(\mu \mathrm{L} / \mathrm{cm}^{2}\right)$ & $\chi^{2}$ & Slope $\pm \mathrm{SE}$ & $\mathrm{Sig}$ & $\begin{array}{l}\text { Degrees } \\
\text { of free- } \\
\text { dom }\end{array}$ \\
\hline Mentha rotundifolia & $0.004(0.0028-$ & $0.017(0.012-$ & 6.95 & $128.74 \pm 51.16$ & 0.008 & 1 \\
& $0.0063)$ & $0.027)$ & & & & \\
Myrtus communis & $0.025(0.016-$ & $0.053(0.034-$ & 1.12 & $58.03 \pm 57.65$ & 0.289 & 1 \\
& $0.041)$ & $0.084)$ & & & & \\
\hline
\end{tabular}

${ }^{\mathrm{a}}$ Units $\mathrm{LC}_{50}$ and $\mathrm{LC}_{95}=\mathrm{mL} / \mathrm{L}$ air. Applied for $24 \mathrm{~h}$ at $25^{\circ} \mathrm{C}$

${ }^{\mathrm{b}} 95 \%$ lower and upper confidence limits are shown in parentheses

\begin{tabular}{lllllll}
\hline Essential oils & $\begin{array}{l}\text { Concentrations } \\
\left(10^{-4} \mu \mathrm{L} / \mathrm{cm}^{2}\right)\end{array}$ & $\mathrm{LT}_{50}^{(\text {a.b) }}$ & $\chi^{2}$ & Slope \pm SE & Sig & $\begin{array}{l}\text { Degrees of } \\
\text { freedom }\end{array}$ \\
\hline Mentha rotundifolia & 9 & $61.73(55.62-69.10)$ & 0.67 & $0.06 \pm 0.014$ & 0.99 & 6 \\
& 24 & $28.76(20.13-35.67)$ & 7.55 & $0.05 \pm 0.01$ & 0.27 & 6 \\
& 99 & $26.58(14.54-35.44)$ & 2.7 & $0.03 \pm 0.008$ & 0.84 & 6 \\
Myrtus communis & 9 & $85.84(72.35-102.16)$ & 8.87 & $0.02 \pm 0.003$ & 0.18 & 6 \\
& 24 & $73.32(64.02-86.05)$ & 5.43 & $0.03 \pm 0.007$ & 0.48 & 6 \\
& 99 & $48.45(42.74-53.90)$ & 2.62 & $0.08 \pm 0.01$ & 0.85 & 6 \\
\hline
\end{tabular}

${ }^{\mathrm{a}}$ Units $\mathrm{LT}_{50}=\mathrm{h}$. Applied at $25^{\circ} \mathrm{C}$

${ }^{\mathrm{b}} 95 \%$ lower and upper confidence limits are shown in parentheses 


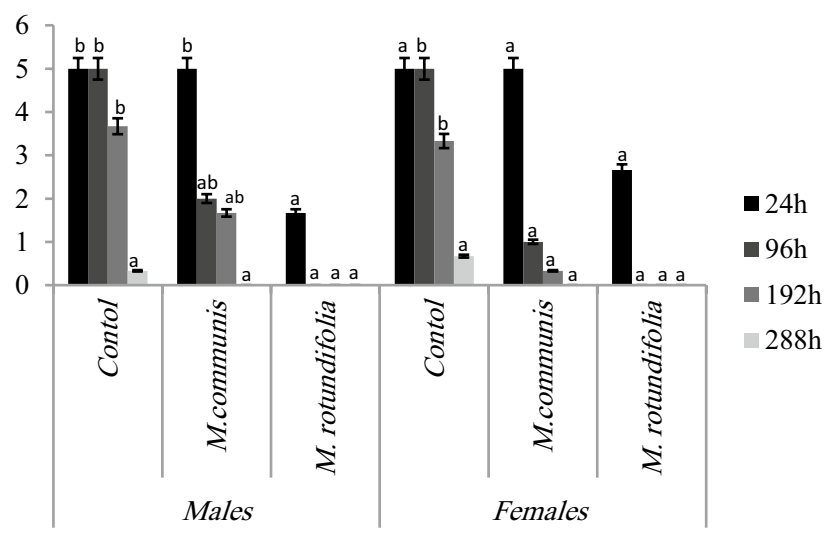

Fig. 3 Effects of Mentha rotundifolia and Myrtus communis essential oils on the longevity of Ephestia kuehniella adults. (For each sex, comparisons were made among essential oils. Different letters are significantly different according to Duncan test at $p \leq 0.05$ )

varied between 86 and $48 \mathrm{~h}$ for the lowest and highest concentration, respectively.

\section{Biological parameters}

\section{Longevity}

Essential oils significantly reduced adults' longevity at LC $_{15}$ concentration (Fig. 3). Statistical analysis showed highly significant differences in longevity as a function of essential oils treatments for both sex [males $\left(F_{2,24}=21.08\right.$, $p<0.01)$, females $\left.\left(F_{2,24}=22.57, p<0.01\right)\right]$, time (males: $F_{3,24}=16.07, p<0.01$; females: $\left.F_{3,24}=23.42, p<0.01\right)$, and their interaction [males $\left(F_{6,24}=2.85, p<0.01\right)$, females $\left.\left(F_{6,24}=3.57, p<0.05\right)\right]$. Moreover, significative differences were observed in the longevity of males adults treated by $M$. rotundifolia and $M$. communis essential oils $\left(F_{1,22}=5.56, p<0.05\right)$, whereas no significative differences were detected in the longevity of females $\left(F_{1,22}=1.32, p>0.05\right.$,

\section{Fecundity, oviposition deterrence, and hatching rate}

According to the data presented in Fig. 4, the fecundity of females was highly dependent on essential oil and exposure time. In fact, the number of eggs laid increased over time, whether in the control or in $M$. communis essential oil treatment. Based on statistical analysis, there is significant differences in fecundity between control and treated females $\left(F_{2,6}=412.81, p<0.01\right)$. The mean number of eggs bequeathed by the untreated females was 178 eggs compared to 93 eggs for the essential oil of M. communis and 6 eggs for M. rotundifolia. As it can be perceived in Fig. 4, the essential oils adversely affected the hatching rate (control: $89 \%$, common myrtle: $57 \%$, round-leaved mint: $0 \%$ ) which decreased over time. Data showed that hatching rate declined significantly with $M$. rotundifolia essential oil treatment $\left(F_{1,4}=148.23, p<0.01\right)$ contrary to $M$. communis treatment $\left(F_{1,4}=3.73, p>0.05\right)$. Furthermore, results showed significant differences in percentage of oviposition deterrence as a function of essential oils treatment $\left(F_{2,6}=21.02, p<0.01\right)$. Mentha rotundifolia showed the high percentage of oviposition deterrence $96.62 \% \pm 1.87$ against $47.85 \% \pm 18.13$ for M. communis.

\section{Fertility and copulation rate of E. kuehniella females}

Results of fertility and copulation rate of E. kuehniella females are illustrated in Table 6. Data showed that fertility and copulation rate significantly depended on essential
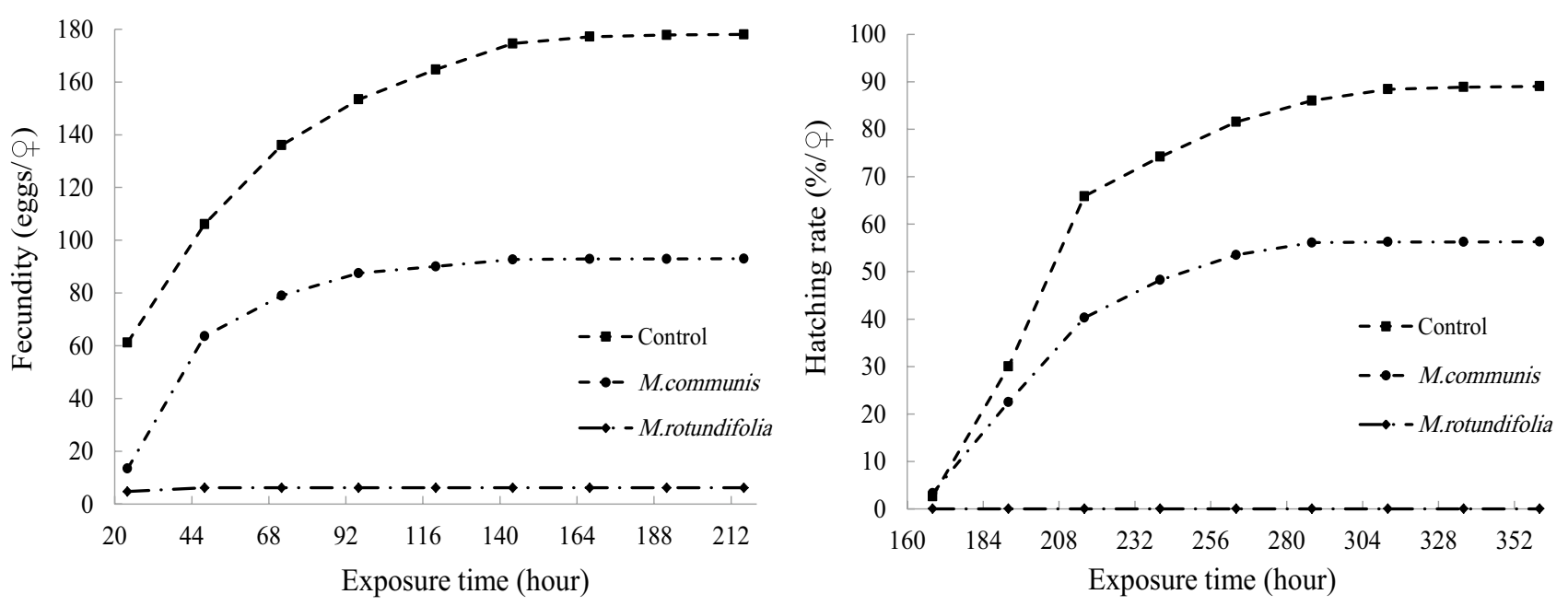

Fig. 4 Effect of Mentha rotundifolia and Myrtus communis essential oils on fecundity and hatching rate of Ephestia kuehniella 
Table 6 Effect of Mentha rotundifolia and Myrtus communis on the fertility and copulation rate of Ephestia kuehniella

\begin{tabular}{lcc}
\hline & Copulation rate (\%) & Log fertility \\
\hline Mentha rotundifolia & $0.00 \pm 0.00^{\mathrm{a}}$ & $0.00 \pm 0.00^{\mathrm{a}}$ \\
Myrtus communis & $53.33 \pm 6.66^{\mathrm{b}}$ & $4.04 \pm 1.39^{\mathrm{b}}$ \\
Control & $100.00 \pm 0.00^{\mathrm{c}}$ & $6.69 \pm 0.14^{\mathrm{c}}$ \\
\hline
\end{tabular}

For each column, values followed by different letters are significantly different according to Duncan test at $p \leq 0.01$ )

oil. Statistical analyses indicated a significant reduction in fertility between control and treated insects $\left(F_{2,6}=14.90\right.$, $p<0.01)$. Significant differences were detected in the copulation rate among control and treatments $\left(F_{2,6}=169\right.$, $p<0.01)$. In control, $100 \%$ of females had been fertilized by the males and had filled spermathecae. Almost $50 \%$ of the females who were treated with $M$. communis oil have been fertilized. Thus, the mating rate had been halved by the action of this oil. Mating rate in females treated with essential oil of M. rotundifolia was null (0\%).

\section{Discussion}

The present study showed that the essential oils of $M$. rotundifolia and M. communis collected from the northeast of Algeria are a promising source of phytochemicals. Mentha rotundifolia yielded $1.29 \%$ which is in accordance with the results reported for the same species in Tunisia 1.26\%, (Riahi et al. 2013). Contrary, M. rotundifolia from other locations of Algeria have higher essential oil yields 1.6-1.8\% (Brada et al. 2007) and 1.65\% (Benabdallah et al. 2018) but lower than those reported in Morocco 1.54\% (Derwich et al. 2009) and $4.33 \%$ (Derwich et al. 2010).

In our case, the yield of M. communis essential oil was $0.64 \%$. This result was in agreement with the studies of Barhouchi et al. (2016) in Algeria (0.6\%) and Aidi Wannes et al. (2007) in Tunisia (0.61\%) but seemed to be higher than those found in Greece $0.28-0.3 \%$ (Gardeli et al. 2008) and Morocco 0.3-0.4\% (Satrani et al. 2006).

In this research, GC/MS analysis revealed 30 compounds in essential oil of $M$. rotundifolia, the major one being piperitenone oxide or rotundifolone (46.06\%). Preceding works pointed out that piperitenone oxide was reported as main constituent of some chemotype of $M$. rotundifolia in diverse geographic areas (Brada et al. 2006, 2007; Benabdallah et al. 2018; Lorenzo et al. 2002; Gende et al. 2014; Bounihi 2016; Sumio 1956). However, Kokkini and Papageorgiou (1988) confirmed that piperitone oxide and menthyl acetate were also two chemotypes of Grecian populations. Moreover, Reitsema (1958) and Lawrence (2007) reported carvone as a principal constituent in M. rotundifolia oils. Similarly, El
Arch et al. (2003) and Riahi et al. (2013) stated pulegone as a major compound, respectively, in Morocco and Tunisia. Other previous studies investigated that the chemical composition of $M$. rotundifolia revealed the presence of specific chemotypes such as trans-piperitone epooxide in Algeria (Brahmi et al. 2016), 2,4(8),6-p-menthatrien-2,3-diol and germacrene D in Cuba (Pino et al. 1999), and menthol in Morocco (Derwich et al. 2009). Many studies reported that piperitenone oxide was also the main constituent of Mentha suaveolens (Oumzil et al. 2002; Amzouar et al. 2016; Maffei 1988; Baser et al. 1999), Mentha longifolia (Venskutonis 1996; Ghoulami 2001), and Mentha villosa (Sousa et al. 2009). In the present study, $M$. communis essential oil was characterized by 1,8 -cineole $(36.82 \%)$ and $\alpha$-pinene $(29.08 \%)$ as major compounds. Likewise, data showed a high level of 1,8-cineole which corroborates the findings of Bouzouita et al. (2003) and Viuda Martos et al. (2011). However, Ben Ghnaya et al. (2013) and Aidi Wannes et al. (2007) stated that two populations of Tunisian M. communis essential oils presented the pair $\alpha$-pinene/1,8-cineole as major compounds with a prevalence for $\alpha$-pinene. Moreover, Barhouchi et al. (2016) reported that $\alpha$-pinene and 1,8-cineole represent together $88 \%$ of common myrtle essential oil from the Northeast of Algeria. Also, Messaoud et al. (2005) investigated twelve Tunisian natural populations of $M$. communis and detected that $\alpha$-pinene and 1,8-cineole were the main volatile components. In the same way, it can be observed that Iranian, French, and Italian myrtle oil revealed the same main mixture: $\alpha$-pinene, 1,8-cineole (Rasooli et al. 2002; Curini et al. 2003; Tuberoso et al. 2006). Chalchat et al. (1998) compared M. communis essential oils from different Mediterranean locations and reported that oils from Corsica and Tunisia presented a level of $\alpha$-pinene above $50 \%$ and Morocco, Lebanon, Yugoslavia oils' presented a level under 35\%. In contrast, Spanish, Croatian, and Grecian common myrtle was characterized by the myrtenyl acetate chemotype (Boelens and Jimenez 1992; Jerkovic et al. 2002; Gardeli et al. 2008), whereas in the present study there was no trace of this compound. Otherwise, the ratio 1,8-cineole, myrtenyl acetate characterized the Moroccan oil (Satrani et al. 2006). Another study from Tizi Ouzou Algeria had shown that 1,8-cineole (47\%) and cis-geraniol (25\%) were the main volatile compounds (Djenane et al. 2011).

As we can observe, there are several chemotypes of Myrtus communis and M. rotundifolia essential oils over the world; this difference in the chemical composition is closely linked to several factors like adaptive metabolism of plant (Nikšić et al. 2014), geographical position, temperature, day length, nutrients, maturation stage, polyploidy (Scora 1973), air movement, rainfall (Boukhebti et al. 2011), harvest period, distillation method, and time of extraction (Rajendran and Sriranjini 2008). 
Plant extracts have been traditionally used around the world to protect stored products, but the recent increased interest in essential oil was observed with the emergence of scientific evidences on their fumigant and contact insecticidal toxicity to a large range of pests (Isman 2000). In fact, essential oils represent excellent alternatives to chemicals because of their low mammalian toxicity, fast degradation, and local obtainability (Rajendran and Sriranjini 2008). Essential oils could be regarded among the new generation of chemicals that interrupt insects' life cycle and thus seen as more target-oriented softer technique of control with less impact on the environment. The essential oils used in the current work showed a potent toxicity to E. kuehniella adults, especially $M$. rotundifolia. Our results demonstrated a high fumigant and contact toxicity and exceptional disruptive effects on the biological parameters of E. kuehniella. Brahmi et al. (2016) and El Arch et al. (2003) have reported the insecticidal activity of $M$. rotundifolia against pest beetles. Furthermore, context of KarabÖrkulü et al. (2011) evaluated the fumigant action of eight essential oils from Turkish aromatic plants including $M$. communis and demonstrated that this oil showed a moderate toxicity with $\mathrm{LC}_{50}$ value of $15.15 \mu \mathrm{L} / \mathrm{L}$ air. In another study, Ayvaz et al. (2010) testified the insecticidal activity (fumigant test) of $M$. communis $\left(\mathrm{LC}_{50}=12.75 \mu \mathrm{L} / \mathrm{L}\right.$ air $)$. This is in contradiction with our results, since we demonstrate that myrtle oil was more efficient with a low lethal concentration $\left(\mathrm{LC}_{50}=2.21 \mu \mathrm{L} / \mathrm{L}\right.$ air). Mediouni Ben Jemâa et al. (2012) studied the impact of seasonal variations on the chemical composition and the fumigant bioassay of five Eucalyptus species essential oils against E. kuehniella and confirmed that all species were characterized by the same major compounds: 1, 8-cineole and $\alpha$-pinene, and Eucalyptus camaldulensis was the toxic one with $\mathrm{LC}_{50}=26.73 \mu \mathrm{L} / \mathrm{L}$ air and $\mathrm{LT}_{50}=30.46 \mathrm{~h}$. Also, $100 \%$ mortality of E. kuehniella larvae was reached by Satureja hortensis essential oil at $228.5 \mu \mathrm{L} / \mathrm{L}$ air after $12 \mathrm{~h}$ of exposure (Maedeh et al. 2011). Similarly, in the study of Emamjomeh et al. (2014), Zataria multiflora exhibited high fumigant toxicity against $E$. kuehniella adults and larvae at $0.98 \mu \mathrm{L} / \mathrm{L}$ air and $20.67 \mu \mathrm{L} / \mathrm{L}$ air $\mathrm{LC}_{50}$, respectively. Also, fumigant toxicity screening on different development stages of E. kuehniella showed the effectiveness of Mentha spicata essential oil with $\mathrm{LC}_{50}$ value of $0.5 \mu \mathrm{L} / \mathrm{L}$ air for adults and eggs mortality reaching 50-60\% (Eliopoulos et al. 2015). In addition, Kheirkhah et al. (2015) noted that E. kuehniella adults were more sensitive to the fumigant effect of Ziziphora clinopodioides oil than larvae $\left(\mathrm{LC}_{50}=1.39 \mu \mathrm{L}\right.$, $42.17 \mu \mathrm{L} / \mathrm{L}$ air). Mediouni Ben Jemâa et al. (2013) conducted fumigant assays using Laurus nobilis essential oil from Algeria and Tunisia against E. kuehniella adults and recorded the superiority of the Algerian oil $\left(\mathrm{LC}_{50}=20.77\right.$, $33.75 \mu \mathrm{L} / \mathrm{L}$ air). Likewise, Ecran et al. (2013) observed that Prangos ferulacea oil was more toxic to E. kuehniella adults $\left(\mathrm{LC}_{50}=1\right)$ than eggs $\left(\mathrm{LC}_{50}=320.37 \mu \mathrm{L} / \mathrm{L}\right.$ air $)$. Pandir and Baş. (2016) recorded that paprica, basil, papermint, and rosemary essential oils were toxic to eggs, larvae, and adults E. kuehniella. Ben Chaaban et al. (2019) proved the fumigant efficacy of Mentha pulegium against $E$. kuehniella adults $\left(\mathrm{LC}_{50}=0.3 \mu \mathrm{L} / \mathrm{L}\right.$ air $)$.

Inhibition of oviposition using essential oils represents a pertinent criterion to control pest infestation and manage stored products (Singh and Pandey 2018). In this respect, Ulukanli et al. (2014) pointed out that essential oils extracted from cortex of Pinus pinea and Pinus brutia presented ovicidal activity on E. kuehniella eggs $\left(\mathrm{LC}_{50}=343\right.$. 57, 299.9 $\mu \mathrm{L} / \mathrm{L}$ air). According to Tunç et al. (2000), cumin and anise induced $100 \%$ mortality of E. kuehniella eggs. Besides, Bachrouch et al. (2010) cited that Pistacia lentiscus was toxic against E. kuehniella $\left(\mathrm{LC}_{50}=1.84 \mu \mathrm{L} / \mathrm{L}\right.$ air $)$ and reduced adults' longevity, fecundity, hatching rate, and copulation rate. Generally, as recorded by Delimi et al. (2013) and Taibi et al. (2018), topical bioassay of Artemisia herbaalba and Origanum vulgaris oils on E. kuehniella chrysalis causes disorders of nymphal duration, disrupts adult reproduction, reduces the longevity of females, and therefore decreases their fecundity.

As reported in this work, strong contact and fumigant toxicities were exhibited by both Algerian essential oils. The round-leaved mint $M$. rotundifolia showed most promising results in terms of adult mortality and impact on biological parameters of the target pest E. kuehniella. Indeed, a complete inhibition of egg hatching and copulation rate was accomplished. Consequently, our results clearly support the application of this oil as a potential biocontrol agent that may be an appropriate alternative for achieving a safer and more sustainable management of stored commodities in Algeria. Therefore, further research including the efficacy of this oil on other stored-product pests (coleopteran species) and its impact on food quality are warranted.

\section{Compliance with ethical standards}

Conflict of interest The author declares that they have no conflict of interest.

Open Access This article is licensed under a Creative Commons Attribution 4.0 International License, which permits use, sharing, adaptation, distribution and reproduction in any medium or format, as long as you give appropriate credit to the original author(s) and the source, provide a link to the Creative Commons licence, and indicate if changes were made. The images or other third party material in this article are included in the article's Creative Commons licence, unless indicated otherwise in a credit line to the material. If material is not included in the article's Creative Commons licence and your intended use is not permitted by statutory regulation or exceeds the permitted use, you will need to obtain permission directly from the copyright holder. To view a copy of this licence, visit http://creativecommons.org/licenses/by/4.0/. 


\section{References}

Abbott W (1925) A method of computing the effectiveness of an insecticide. J Econ Entomol 18(2):265-267

Abdelgaleil SAM, Mohamed MIE, Badawy MEI, El-Arami SAA (2009) Fumigant and contact toxicities of monoterpenes to Sitophilus oryzae (L.) and Tribulium castaneum (Herbst) and their inhibitory effects on acetylcholinesterase activity. J Chem Ecol 35:518-525

AFNOR (1986) Recueil des normes Françaises «huiles essentielles». AFNOR, Paris

Aidi Wannes W, Mhamdi B, Marzouk B (2007) Essential oil composition of two Myrtus communis L. varieties grown in North Tunisia. Ital J Biochem 56(2):180-186

Al-Izzi MAJ, Al-Maliky SK, Younis MA, Jabbo NF (1985) Bionomics of Ectomyelois ceratoniae (Lepidoptera: Pyralidae) on Pomegranates in Irak. Environ Entomol 14(2):149-153

Amzouar S, Boughdad A, Maatoui A, Allam L (2016) Comparison of the chemical composition and the insecticidal activity of essential oils of Mentha suaveolens Ehrh collected from two different regions of Morocco, against Bruchus rufimanus (Bohman) (Coleoptera: Chrysomelidae). Int J Innov Appl Stud 18(3):836-845

Ayvaz A, Sagdic O, Karaborklu S, Ozturk I (2010) Insecticidal activity of the essential oils from different plants against three storedproduct insects. J Insect Sci 10(21):1-13

Bachrouch O, Mediouni Ben Jemâa J, Aidi Waness W, Talou T, Marzouk B, Abderraba M (2010) Composition and insecticidal activity of essential oil from Pistacia lentiscus L. against Ectomyelois ceratoniae Zeller and Ephestia kuehniella Zeller (Lepidoptera: Pyralidae). J Stored Prod Res 46(4):242-247

Barhouchi B, Aouadi S, Abdi A (2016) Essential oil chemical composition of myrtle growing in Northeastern Algeria and estimation of its antibacterial effectiveness. Am J Biochem Biotechnol 12(2):110-121

Baser K, Kürkçüoglu M, Tarimcilar G, Kaynak G (1999) Essential oils of Mentha species from Northern Turkey. J Essent Oil Res 11(5):579-588

Ben Achour N, Messoudi S, Mediouni Ben Jemâa J, Ben Ammar A, Belhadj O (2008) Isolation of Bacillus thuringiensis strains active against Ceratitis capitata and Ephestia kuehniella in Tunisia. Microbiologie et hygiène alimentaire 20:35-39

Ben Chaaban S, Haouel Hamdi S, Mahjoubi K, Mediouni Ben Jemâa J (2019) Composition and insecticidal activity of essential oil from Ruta graveolens, Mentha pulegium and Ocimum basilicum against Ectomyelois ceratoniae Zeller and Ephestia kuehniella Zeller (Lepidoptera: Pyralidae). J Plant Dis Prot 126(3):237-246

Ben Ghnaya A, Chograni H, Messoud C, Boussaid M (2013) Comparative chemical composition and antibacterial activities of Myrtus communis L. Essential oils isolated from Tunisian and Algerian population. J Plant Pathol Microbiol 4(7):186

Benabdallah A, Boumendjel M, Aissi O, Rahmoune C, Boussaid M, Messaoud M (2018) Chemical composition, antioxidant activity and acetylcholinesterase inhibitory of wild Mentha species from northeastern Algeria. South Afr J Bot 116:131-139

Boelens M, Jimenez R (1992) The Chemical composition of Spanish Myrtle oils: part II. J Essent Oil Res 4(4):349-353

Boukhebti H, Chaker A, Belhadj H, Sahli F, Laouer H, Harzallah D (2011) Chemical composition and antibacterial activity of Mentha pulegium L. and Mentha spicata L. essential oils. Sch Res Libr 3(4):267-275

Bounihi A (2016) Criblage phytochimique, étude toxicologique et valorisation pharmacologique de Melissa officinalis et de Mentha rotundifolia (Lamiacée) [Thèse de doctorat]. Université Mohamed $\mathrm{V}$, Faculté de médecine et de pharmacie, Rabat
Bouzouita N, Kachouri F, Hamdi M, Chaabouni M (2003) Antimicrobial activity of essential oils from Tunisian aromatic plants. Flavour Fragr J 18(5):380-383

Brada M, Bezzina M, Marlier M, Lognay G (2006) Chemical composition of the leaf oil of Mentha rotundifolia (L.) from Algeria. J Essent Oil Res 18:663-665

Brada M, Bezzina M, Marlier M, Carlier A, Lognay G (2007) Variabilité de la composition chimique des huiles essentielles de Mentha rotundifolia du Nord de l'Algérie. Base En Ligne 11(1):1-4

Brahmi F, Abdenour A, Bruno M, Silvia P, Alessandra P, Danilo F, Yalaoui-Guellal D, Elsebai MF, Madani K, Chibane M (2016) Chemical composition and in vitro antimicrobial, insecticidal and antioxidant activities of the essential oils of Mentha pulegium $\mathrm{L}$. and Mentha rotundifolia L. Huds growing in Algeria. Ind Crops Prod 88:96-105

Cetin H, Erler F, Yanikoglu A (2004) Larvicidal activity of a botanical natural product AkseBio2, against Culex pipiens. Fitoterapia 75(7-8):724-728

Chalchat J, Garry R, Michet A (1998) Essential oils of Myrtle (Myrtus communis L.) of the Mediterranean littoral. J Essent Oil Res 10(6):613-617

Chang Y, Lee SH, Na JH, Chang PS, Han J (2017) Protection of grain products from Sitophilus oryzae (L.) contamination by anti-insect pest repellent sacher containing allyl mercaptan microcapsule. J Food Sci 82(11):2634-2642

Curini M, Bianchi A, Epifano F, Bruni R, Torta L, Zambonelli A (2003) Composition and in vitro antifungal activity of essential oils of Erigeron canadensis. Chem Nat Compd 39(2):191-194

Delimi A, Taibi F, Fissah A, Gherib S, Bouhkari M (2013) Bioactivité des huiles essentielles de l'armoise blanche Artemessia herba alba: effet sur la reproduction et la mortalité des adultes d'un ravageur des denrées stockées Ephestia kuehniella (Lepidoptera). Afr Sci 9(3):82-90

Derwich E, Benziane Z, Boukir A, Benaabidate L (2009) GC-MS analysis of the leaf essential oil of Mentha rotundifolia, a traditional herbal medicine in Morocco. Chem Bull Politech Univ Timisora 54(2):85-88

Derwich E, Benziane Z, Boukir A (2010) Antibacterial activity and chemical composition of the leaf essential oil of Mentha roçdifolia from Morocco. Electron J Environ Agric Food Chem 9(1):19-28

Djenane D, Yangüela J, Amrouche T, Boubrit S, Boussad N, Roncalés P (2011) Chemical composition and antimicrobial effects of essential oils of Eucalyptus globulus, Myrtus communis and Satureja hortensis against Escherichia coli $\mathrm{O}_{157}: \mathrm{H}_{7}$ and Stapphylococcus aureus in minced beef. Food Sci Technol Int 17(6):505-515

Ebadollahi S (2013) Essential oils isolated from Myrtaceae family as natural insecticides. Ann Rev Res Biol 3(3):148-175

Ecran F, Baş H, Koç M, Pandir D, Öztemiz S (2013) Insecticidal activity of essential oil of Prangos ferulace (Umbrelliferar) against Ephestia kuehniella (Lepidoptera: Pyralidae) and Trichogramma embryophagum (Hymenoptera: Trichogrammatidae). Turk J Agric For 37:719-725

El Arch M, Satrani B, Farah A, Bennani L, Boriky D, Fechtal M, Blaghen M, Talbi M (2003) Composition chimique et activité antimicrobienne et insecticide de l'huile essentielle de Mentha rotundifolia du Maroc. Acta Bot Gallica 150(3):267-274

Eliopoulos P, Hassiotis C, Andreadis S, Porichi A (2015) Fumigant toxicity of essential oils from basil and spearmint against two major pyralid pests of stored products. J Econ Entomol 108(2):805-810

Emamjomeh L, Imani S, Talebi K, Moharramipour S, Larijani K (2014) Chemical composition and insecticidal activity of essential oil of Zataria multiflora Boiss (Lamiaceae) against Ephestia kuehniella (Lepidoptera: Pyralidae). Pelagia Res Libr 4(3):253-257 
Gardeli C, Vassiliki P, Athanasios M, Kibouris T, Komaitis M (2008) Essential oil composition of Pistacia lentiscus L. and Myrtus communis L.: evaluation of antioxidant capacity of methanolic extracts. Food Chem 107(3):1120-1130

Gende L, Mendiara S, Fernandez N, Baren C, Lira D, Bandoni A, Fritz R, Floris I, Eguaras M (2014) Essential oils of some Mentha spp. and their relation with antimicrobial activity against Paeni bacillus larvae, the causative agent of American foulbrood in honey bees, by using the bio-autography technique. Bull Insectol 67(1):13-20

Ghoulami S (2001) Phytochemical study of Mentha longifolia of Morocco. Fitoterapia 72(5):596-598

Hami M, Taibi F, Smagghe G, Soltani Mazouni N (2005) Comparative toxicity of three ecdysone agonist insecticides against the Mediterranean flour moth. Commun Agri Appl Biol Sci Ghent Univ 70(4):767-773

Hori M (2003) Repellency of essential oils against the cigarette beetle, Lasioderma serricorne (Fabricius) (Coleoptera: Anobiidae). Appl Entomol Zool 38(4):467-473

Huang Y, Tan JMWL, Kini RM, Ho SH (1997) Toxic and Antifeedant action of nutmeg oil against Tribulium castaneum (Hurbst) and Sitophilus zeamais Motsch. J Stored Prod Res 33(4):289-298

Isman M (2000) Plant essential oils for pest and disease management. Crop Prot 19:603-608

Isman MB, Grieneisen ML (2014) Botanical insecticide research: many publication, limited useful data. Trends Plant Sci 19:140-145

Jacob T, Cox P (1977) The influence of temperature and humidity on the life-cycle of Ephestia kuehniella Zeller (Lepidoptera: Pyralidae). J Stored Prod Res 13(3):107-118

Jarraya A (2003) Principaux nuisibles des plantes cultivées et des denrées stockées en Afrique du nord: leur biologie, leurs ennemies naturels, leurs dégâts et leur contrôle, Maghreb Ed, Tunisia

Jerkovic I, Radonic A, Borcic I (2002) Comparative study of leaf, fruit and flower essential oils of Croatian Myrtus communis (L.) during a one-year vegetative cycle. J Essent Oil Res 14(4):266-270

Jitendra K, Nitin K, Kulkarni D (2009) Plant-based pesticides for control of Helicoverpa amigera on Cucumis sativus. Asian Agric Hist 13(4):327-332

Johnson J, Valero K, Hannel M (1997) Effect of low temperature storage on survival and reproduction of Indian meal moth (Lepidoptera: Pyralidae). Crop Prot 16(6):519-523

KarabÖrkulü S, Ayvaz A, Yilmaz S, Akbulut M (2011) Chemical composition of some essential oils against Ephestia kuehniella. J Econ Entomol 104(4):1212-1219

Kasrati A, Aloui Jamali C, Bekkouche K, Spooner-Heart R, Leach D, Abbad A (2015) Chemical characterization and insecticidal properties of essential oils from different wild population of Mentha suaveolens subsp, timija (Briq.) Harley from Morocco. Chem Biodivers 12:823-831

Khani A, Farzaneh B (2012) Chemical composition and insecticidal activity of Myrtle (Myrtus communis L.) essential oil against two stored-product pests. J Med Plant By-Prod 2:83-89

Kheirkhah M, Ghasemi V, Yazdi A, Rahban S (2015) Chemical composition and insecticidal activity of essential oil from Ziziphora clinopodioides Lam used against the Mediterranean flour moth, Ephestia kuehniella Zeller. J Plant Prot Res 55(3):260-265

Kim S, Roh J, Kim D, Lee H, Ahn Y (2003) Insecticidal activities of aromatic plant extracts and essential oils against Sitophilus oryzae and Callosobruchus chinensis. J Stored Prod Res 39:293-303

Kokkini S, Papageorgiou V (1988) Constituents of essential oils from Mentha $X$ rotundifolia growing wild in Greece. Planta Med 54(2):166-167

Kostyukovsky M, Rafaeli A, Gileadi C, Demchenko N, Shaaya E (2002) Activation of octopaminergic receptors by essential oil constituents isolated from aromatic plants: possible mode of action against insect pests. Pest Manag Sci 58(11):1101-1106
Lawrence B (2007) Mint: the genus Mentha. Medicinal and aromatic plants-industrial profiles. CRC Press, Boca Raton

Liu ZL, Ho SH (1999) Bioactivity of the essential oil extracted from Evodia rutaecarpa Hook f. et Thomas against the grain storage insects, Sitophilus zeamais Motsch and Tribulium castaneum (Hurbst). J Stored Prod Res 35:317-328

Lorenzo D, Paz D, Dellacassa E, Davies P, Vila R, Canigueral S (2002) Essential oils of Mentha pulegium and Mentha rotundifolia from Uruguay. Braz Arch Biol Technol 54(4):519-524

Maedeh M, Hamzeh I, Hossein D, Majid A, Reza R (2011) Bioactivity of essential oil from Satureja hortensis (Lamiaceae) against three stored-product insect species. Afr J Biotechnol 10(34):6620-6627

Maffei M (1988) A chemotype of Mentha longifolia (L.) Hudson particularly rich in piperitenone oxide. Flavour Fragr J 3(1):23-26

Mami Maazoun A, Ben Hlel T, Haouel Hamdi S, Belhadj F, Mediouni Ben Jemâa J, Marzouki M (2017) Screening for insecticidal potential and acetylcholinesterase activity inhibition of Urginea maritima bulbs extract for the control of Sitophilus oryzae (L.). J Asia Pac Entomol 20(3):752-760

Mediouni Ben Jemâa J (2014) Essential oil as source of bioactive constituents for the control of insect pests of economic importance in Tunisia. Med Aromat Plants 3(2):518-525

Mediouni Ben Jemâa J, Haouel S, Bouaziz M, Khouja M (2012) Seasonal variations in chemical composition and fumigant activity of five Eucalyptus essential oils against three moth pests of stored dates in Tunisia. J Stored Prod Res 48:61-67

Mediouni Ben Jemâa J, Tersim N, Boushih E, Taleb-Toudert K, Khouja M (2013) Fumigant control of the Mediterranean flour moth Ephestia kuehniella with the Nobel Laurel Laurus nobilis essential oils. Tunis J Plant Prot 8(1):33-44

Messaoud C, Zaouali Y, Ben Salah A, Khoudja M, Boussaid M (2005) Myrtus communis in Tunisia: variability of the essential oil composition in natural populations. Flavour Fragr J 20(6):577-582

Nerio L, Olivero-Verbal J, Stashenko E (2009) Repellent activity of essential oils from seven aromatic plants growing against Sitophilus zeamais Motschulsky (Coleoptera). J Stored Prod Res 45:212-214

Nikšić H, Kovač-Bešović E, Durić K, Korać N, Omeragić E, Muratović S (2014) Seasonal variation in content and chemical composition of essential oils from leaves of Mentha longifolia Huds. (Lamiaceae). Bull Chem Technol Bosnia Herzeg 43:29-34

Nishimura H (2001) Aroma constituents in plants and their repellent activities against mosquitoes. Aroma Res 2:257-267

Oumzil H, Ghoulami S, Rhajaoui M, Ilidrissi A, Fkih Tetouani S, Faid M, Benjouad M (2002) Antibacterial and antifungal activity of essential oils of Mentha suaveolens. Phytother Res 16(8):727-731

Pandir D, Baş H (2016) Compositional analysis and toxicity of four plant essential oils ti different stages of Mediterranean flour moth, Ephestia kuehniella Zeller (Lepidoptera: Pyralidae). Türk Entomol Derg 40(2):185-195

Pascual Villalobos M, Robledo A (1998) Screening for anti-insect activity in Mediterranean plants. Ind Crops Prod 8(3):183-194

Pino J, Rosado A, Fuentes V (1999) Chemical composition of the leaf oil of Mentha rotundifolia (L.) Hudson from Cuba. J Essent Oil Res 11(2):241-242

Prajapati V, Tripathi AK, Aggarwal KK, Khanuja SPS (2005) Insecticidal, repellent and oviposition-deterrent activity of selected essential oils against Anopheles stephensi, Aedes aegypti and Culex quinquefasiatus. Biores Technol 96:1749-1757

Quan M, Liu Q, Liu Z (2018) Identification of insecticidal constituents from the essential oil from the aerial parts Stachys riederi var japonica. Molecules 23(5):1-12

Rahman S, Biswas S, Barman N, Ferdous T (2016) Plant extract as selective pesticide for integrated pest management. Biotechol Res J 2(1):6-10 
Rajendran S, Sriranjini V (2008) Plant products as fumigants for stored-product insect control. J Stored Prod Res 44(2):126-135

Rasooli I, Moosavi ML, Rezaee MB, Jaimand K (2002) Susceptibility of microorganisms to Myrtus communis L essential oil and its chemical composition. J Agric Sci Technol 4:127-133

Reitsema R (1958) A biogenetic arrangement of Mint species. J Am Pharm Assoc Sci Ed 47(4):267-269

Riahi L, Elferchichi M, Ghazghazi H, Jebali J, Aouadhi C, Chogran H, Zaouali Y, Zoghlami N, Mliki A (2013) Phytochemistry, antioxidant and antimicrobial activities of the essential oils of Mentha rotundifolia $\mathrm{L}$. in Tunisia. Ind Crops Prod 49:883-889

Sangha JS, Astatkie T, Cutler GC (2017) Ovicidal, larvicidal and behavioural effects of some plant essential oils on diamondback moth (Lepidoptera: Plutellidae). Entomol Soc Can 149(5):639-648

Satrani B, Farah A, Talbi M (2006) Effet de la distillation fractionnée sur la composition chimique et l'activité antimicrobienne des huiles essentielles du Myrte (Myrtus communis L.) du Maroc. Acta Bot Gallica 153(2):235-242

Scora R (1973) Essential leaf oil variability in green, variegated and albino foliage of Myrtus communis. Phytochemistry 12(1):153-155

Senfi F, Safaralizadeh MH, Safavi SA, Aramideh S (2013) Fumigant toxicity of Laurus nobilis and Myrtus communis on larvae and adults of the red flour beetle, Tribulium castaneum Herbst (Col.: Tenebrionidae). Arch Phytopathol Plant Prot. https://doi. org/10.1080/03235408.2013.812819

Singh P, Pandey A (2018) Prospective of essential oils of the Genus Mentha as biopesticides: a review. Front Plant Sci 9:1-14

Sousa P, Linard C, Azevedo Batista D, Oliveira AC, Coelho de Souza A, Leal Cardoso J (2009) Antinociceptive effects of the essential oil of Mentha $\times$ villosa leaf and its major constituent piperitenone oxide in mice. Braz J Med Biol Res 42(7):655-659

Sumio S (1956) Studies of the essential oil of Mentha rotundifolia: part I. Isolation of Rotundifolone, a new terpenic ketone. Bull Agric Chem Soc Jpn 20(2):84-88

Taibi F, Boumendjel M, Moncef Z, Omar S, Khaldi T, Delimi A, Abdessmad $\mathrm{S}$, Rebani $\mathrm{H}$, Chnouga $\mathrm{H}$, Siakhène $\mathrm{N}$, Boumendjel A, Messarah M (2018) Conservation of stored food using plant's extracts. Effect of Oregano (Oreganum vulgaris) essential oils on the reproduction and development of flour moth (Ephestia kuehniella). Cell Mol Biol 64(10):5-11

Tayoub G, Abu Elnaser A, Ghanem E (2012) Fumigant activity of leaf essential oil from Myrtus communis L. against the Khapra beetle. Int J Med Arom Plant 2(1):207-213

Titouhi F, Amri M, Messaoud C, Haouel S, Youssfi S, Cherif A, Mediouni Ben Jemâa J (2017) Protective effects of three Artemisia essential oils against Callosobruchus maculatus and Bruchus rufimanus (Coleoptera: Chrysomelidae) and the extended side-effects on their natural enemies. J Stored Prod Res 72:11-20

Tuberoso C, Barra A, Angioni A, Sarritzu E, Pirisi F (2006) Chemical composition of volatiles in Sardinian Myrtle (Myrtus communis L.) alcoholic extracts and essential oils. J Agric Food Chem 54(4):1420-1426

Tunç I, Berger B, Erler F, Dagli F (2000) Ovicidal activity of essential oils from five plants against two stored-product insects. J Stored Prod Res 36:161-168

Ulukanli Z, Karabörklü S, Bozok F, Ates B, Erdogan S, Cenet M, Karaaslan MG (2014) Chemical composition, antimicrobial, insecticidal, phytotoxic and antioxidant activities of Mediterranean Pinus brutia and Pinus pinea resin essential oils. Chin J Nat Med 12(12):901-910

Venskutonis P (1996) A chemotype of Mentha longifolia L. from Lithuania rich in piperitenone oxide. J Essent Oil Res 8(1):91-95

Viuda Martos M, Sendra E, Pérez Alvarez J, Fernández López J, Amensour M, Abrini J (2011) Identification of flavonoid content and chemical composition of the essential oils of Moroccan herbs: Myrtle (Myrtus communis L.), Rockrose (Cistus ladanifer L.) and Montpellier cistus (Cistus monspeliensis L.). J Essent Oil Res 23(2):1-9

Waliwitiya R, Kennedy CJ, Lowenberger CA (2009) Larvicidal and oviposition-altering activity of monoterpenoids, trans-anethole and rosemary oil to the yellow fever mosquito Aedes aegypti (Diptera: Culicidae). Pest Manag Sci 65:241-248

Publisher's Note Springer Nature remains neutral with regard to jurisdictional claims in published maps and institutional affiliations. 